\title{
Political Pop, Political Fans? A Content Analysis of Music Fan Blogs
}

\author{
MARK PEDELTY AND LINDA KEEFE
}

\section{Introduction}

Tori Amos believes “the dangerous thing about listening [to music] is that you don't really know the effect it's going to have". ${ }^{1}$ That applies to making music as well. Performers can never really be certain what effect their music has on fans. Few artists believe that their music will rally audiences to action, but many hope that it will at least serve as a catalyst for discussion. For example, Rage Against the Machine's Zack de la Rocha writes lyrics in the belief that music might "spark" a "real dialogue."2

Unfortunately, little research has been done to determine to what extent, if any, audiences care about the political elements of pop. As ethnographers our work has mainly involved qualitative research with individuals who make and consume music, including extensive field-based ethnography. Specifically, we have been involved in participant observation and interviews with musicians interested in the political potential of music. ${ }^{3}$ Yet, we often wonder how our intersubjective engagement in the lives, minds, and actions of individuals and small groups relates to larger scale discourses, and to larger audiences. Therefore, to achieve the holistic aims of ethnography, we decided to supplement our qualitative fieldwork with quantitative analysis of fan discourse.

Does political music "spark" a "real dialogue" among fans, as Zack de la Rocha had hoped? Based on previous interviews and ethnographic fieldwork, we hypothesized that it would. No claim for causation is possible here, however; the best we can do is to determine whether or not fans of political pop engage in political dialogue, and to what extent they do so when compared to fans of less politicallycharged music.

Based on the quantitative content analysis detailed here, it is safe to say that political discussion is taking place among fans. Our research demonstrates that political discussion is more frequent among fans of musicians with political reputations than it is among fans of top-selling pop stars. While this conclusion will be qualified and contextualized, the analysis serves as some of the strongest evidence to date, showing that the politics of pop is relevant to general audiences.

What fans have to say to researchers depends on many factors, including time, location, and research instruments and design. Surveys at performances yield one set of data, while interviews of iPod users in cafes provide another. We sought a natural setting and exogenous source, discussions that take

\footnotetext{
${ }^{1}$ T. Gracyk, I wanna be me: Rock music and the politics of identity (Philadelphia: Temple University Press, 2001), 225.

${ }^{2}$ C. Devenish, Rage Against the Machine (New York: St. Martin's Press, 2001), 124.

${ }^{3}$ A complete explanation of our ethnographic work is neither possible nor useful in this context. However, for sake of background, our work has involved participatory action research and participant observation fieldwork at local clubs and concerts working as a band, interviewing and experiencing audiences, interviewing and observing fellow musicians, and surveying activists interested in musical politics, i.e., particularistic, humanistic exploration of a specific subset of musical artist and fan. This work grew out of our interest in gaining a more generalized sense of how fans of musicians typically defined as "political" relate to those musicians. While the ethnographic work is semiotically deep and particularistic, this work, like all quantitative research, is numerically broad and contextual.
} 
place without a research prompt: fan blogs. Granted, bloggers represent a particular type of audience. Such fans have enough interest in musicians and music to actively write about them. As such, this is a study of serious fans in a computer-mediated communication (CMC) context. Fan blogs are a great place to start, for determining whether or not fans of political pop musicians engage in more political discourse than pop fans in general.

\section{The Literature}

Although music is clearly central to political movements and rituals, it is not clear how, or even if, general audiences relate to pop music on a political level. Even in the case of overtly political pop acts like U2, the Clash, or Rage Against the Machine, it is not clear to what extent the political messages in and around the music motivate fans, become a catalyst for discussion, function aesthetically, or play very little role at all in fan attraction.

Political meaning is hard to pin down in song, even when focusing on lyrics. People react as much or more to the "feel" of a given song as to the manifest meanings of the words. For example, Prinsky determined that most teenagers ignore lyrics. That is why censorship tends to backfire. Instead of keeping a song from audiences, censorship tends to serve as a cue for young listeners to pay more attention to lyrics. ${ }^{4}$ As Frith explains, lyrics are just part of the musical gestalt, less autonomous in their meaning than other types of text. Lyrical meaning is intimately linked to, and conditioned by, semiotic cues in the music and performance, such as vocal inflection, rhythm, and musical tone. ${ }^{5}$

It is extremely difficult to predict how audiences will respond to musical words, sounds, or even visual cues. For example, Bleich and Zillmann found that "counter to expectations, highly rebellious students did not enjoy defiant rock videos more than did their less rebellious peers, nor did they consume more defiant rock music than did their peers." ${ }^{\prime 6}$ In that case, there was very little connection between behavior and musical taste.

The difficulty in predicting and understanding an audience's musical interpretations and orientations is partly due to the fact that there is an extremely diverse range of cues, codes, and contexts involved in musical production, distribution, and consumption. Platoff illustrated the complex nature of audience interpretation using the example of John Lennon's "Revolution" (1968). He argued that reactions to the song "had much to do not just with the song itself but with public perceptions of the Beatles." Interpretations of the song were also influenced by contemporary events and social trends, such as deepening anger concerning the war in Vietnam. Although both liberal and conservative critics tended to give strong readings to the lyrics of both versions of "Revolution," most audiences based their interpretations on the musical tone and mood of the song rather than referencing the more nuanced meanings expressed in Lennon's lyrics.

Likewise, Robinson and Hirsch found that teenagers generally did not recognize the basic topics of pop songs. ${ }^{8}$ As further evidence of this, Denisoff and Levine determined that half of the college students

\footnotetext{
${ }^{4}$ L. Prinsky, “Leer-ics' or lyrics: Teenage impressions of rock 'n' roll,” Youth E Society 18, vol. 4 (1987): $384-397$.

${ }^{5}$ S. Frith, Performing rites: On the value of popular music (Cambridge, MA: Harvard University Press, 1996), $158-182$.

${ }^{6}$ S. Bleich and D. Zillmann, "Enjoyment and consumption of defiant rock music as a function of adolescent rebelliousness," Fournal of Broadcasting \& Electronic Media 35, vol. 3 (1991): 351.

${ }^{7}$ J. Platoff. “John Lennon,,'Revolution,' and the politics of musical reception,” Fournal of Musicology 22, vol. 2 (2005): 241.

${ }^{8}$ J.P. Robinson and P. M. Hirsch, "Teenage response to rock and roll protest songs," in The sounds of social change: Studies in
} 
involved in their study could not correctly identify the topic of Barry McQuire's "Eve of Destruction" (1965), even after reading the lyrics. ${ }^{9}$ While these and most quantitative studies of popular music are significantly dated, they lead us to wonder what message politicized pop songs actually convey, if any.

As opposed to the research cited above, most studies of musical politics have involved interpretive readings of lyrics and/or performances with a strong emphasis on historical contexts, ${ }^{10}$ links to social groups, ${ }^{11}$ musical movements, ${ }^{12}$ and various combinations of contexts. ${ }^{13}$ If there is consensus in the qualitative literature it is this: given the right historical circumstances, cultural conditions, and aesthetic qualities, popular music can help bring people together to form effective political communities.

The above studies and others have provided a useful overview of how political pop functions, at least in specific cases. Although it is evident that activists are interested in political pop, it is still not clear how, or even if, popular political artists like U2, the Clash, Rage Against the Machine, and others connect with their larger fan base. For all we know, most of their fans have no interest in their favorite pop stars' political messages. One could certainly imagine a Rage Against the Machine fan enjoying Tom Morello's inventive guitar riffs while banging about in the mosh pit at a RATM concert, mostly indifferent or perhaps even antagonistic to the socialist politics of the band. Such people would consider themselves RATM fans and most RATM fans might even share an apolitical orientation to music. In other words, in terms of political interest, identification, and communication, fans of political pop might be much more like the general pop audience than is often assumed. That is the primary question we are exploring here.

The only empirical evidence of political concordance between pop stars and their fans comes from studies involving college students. Although the general pop audience might not listen closely enough to lyrics to understand its manifest meanings, political or otherwise, there is evidence that politics plays some role in fan identification among some groups of college students. For example, Fox and Williams found that among college students "musical styles are associated with ideological orientations," even though few overtly political traits are evident in the music itself. ${ }^{14}$ More recently, Jackson and Darrow found that young adults' level of agreement with political statements tended to increase when those statements were endorsed by music and sports stars. ${ }^{15}$

Weglarz further advanced our understanding of the relationship between musical taste and politics, making the analysis more fine-grained by studying fan attraction to individual artists as opposed to the broader genre categories studied by Fox and Williams. Weglarz found a positive relationship

popular culture, ed. R. S. Denisoff and R. A. Peterson (Chicago: Rand McNally, 1972), 222-231.

${ }^{9}$ R. S. Denisoff and M. H. Levine, "Brainwashing or background noise: The popular protest song," in The sounds of social change: Studies in popular culture, ed. R. S. Denisoff and R. A. Peterson. (Chicago: Rand McNally, 1972), $213-221$.

${ }^{10}$ D. Margolick, Strange fruit: Billie Holiday, café society, and an early cry for civil rights (Philadelphia: Running Press, 2000).

${ }^{11}$ M. Mattern, Acting in concert: Music, community, and political action (New Brunswick, NJ: Rutgers University Press, 1998).

${ }^{12}$ R.Garofalo, B. Bragg, T.Cheng, S. Fast, S. Frith, H. George-Warren, et al., "Who is the world?: Reflections on music and politics twenty years after live aid," Fournal of Popular Music Studies 17, vol 3 (2005).

${ }^{13}$ R. Pratt, Rhythm and resistance: The political uses of American popular music (Washington: Smithsonian Institution Press, 1994).

${ }^{14}$ W. S. Fox, and J. D.Williams, "Political orientation and music preference among college students," Public Opinion Quarterly 38, vol. 3 (1974): 371

${ }^{15}$ D. J. Jackson and T. I. A. Darrow, "The influence of celebrity endorsements on young adults' political opinions," Harvard International Fournal of Press/Politics 10, vol. 3 (2005): 80-98. 
between students' political views and those of the musicians they enjoy. Weglarz's research among college students is the best evidence yet of political concordance between fans and musicians. ${ }^{16}$

We studied the question via quantitative analysis of fan blogs in order to examine fan communication in a more natural setting. As opposed to communication impelled by surveys or experiments, blogs have a heuristic advantage: they are not produced via experiment or artificial prompt. They already exist in the world, having been created for and by fans. Therefore, the blogosphere is an excellent place to measure the relative level of political discourse in fan communication.

\section{Method}

Two samples were compared: (1) blogs written by fans of top-selling pop artists and (2) blogs written by fans of political pop musicians.

We selected the top-selling musician for each fifth year between 1960 and 2005, using Billboard Magazine charts, resulting in the following list: the Beatles, Bruce Springsteen, Elton John, 50 Cent, Hootie and the Blowfish, Janet Jackson, Kingston Trio, Pink Floyd, Paul Simon, and 'N Sync. A problem was encountered in defining the sample: a few of the top-selling artists could also be defined as "political," potentially creating overlap between samples. Certainly Bruce Springsteen is in that category, and others might be moved there as well depending on one's definition of "political."

However, we decided not to change the selection method for two reasons. First, the top-selling pop category is more inclusive. It represents, quite literally, the most popular music. As the more inclusive category, it is possible that top-selling artists might also have some political content in their music or performances. For us to gerrymander the list of top-selling artists by removing those we might define as political would be to insert our own bias into the results.

Having determined which musicians would represent the top-selling pop category, we used a systematic sampling method and the Google Blogs search tool to collect 10 fan blogs for each of the 10 top-selling artists, resulting in a total of 100 fan blogs.

Choosing a representative sample of "political pop" musicians was more complicated. Given the diversity of political perspectives and definitions, no single sample could possibly represent "political pop musicians" as an entire class. The boundaries of such a population would be too indefinite and the rules for inclusion too subjective. A specific category of political musicians had to be selected, using an exogenous source. However, first we needed to define the political field in question.

Much of the literature concerning American political pop has emphasized movement and protest traditions. ${ }^{17}$ Therefore, we chose to look at music and musicians associated with the following political movements: environment, human rights, peace, and labor. Those movements and issues have garnered much of the attention in popular music and associated popular music research. ${ }^{18}$ While disagreeing

\footnotetext{
${ }^{16}$ K. Weglarz, "From music to voting blocs: An analysis of popular musicians and political persuasion," paper presented at the Annual Conference of the International Association for the Study of Popular Music, St. Catharines, Ontario, Canada, May 2008.

${ }^{17}$ See D.Fischlin, Rebel Musics: Human rights, resistant sounds, and the politics of music making (Montréal: Black Rose Books, 2003) and J. Rodnitsky, "The decline and rebirth of folk-protest music," in The resisting muse: Popular music and social protest, ed. I. Peddie (London: Ashgate. 2006), 17-29.

${ }^{18}$ See M. Drewett, "The eyes of the world are watching now: The political effectiveness of "Biko" by Peter Gabriel," Popular Music E Society 30 (2007); R. Garofalo, Rockin’ the boat: Mass music and mass movements (Boston: South End Press, 1992); and D. Margolick, Strange fruit: Billie Holiday.
} 
vociferously over the nature of mainstream popular culture, critics from both the Left and Right agree that overtly politicized pop tends to evidence a leftward bent in the USA. ${ }^{19}$

To develop an exogenous sample of "political musicians," we administered a simple survey to labor, peace, environmental, and human rights activists. They were asked for examples of musicians who had influenced them in open-ended questions. General calls for participation in the survey were posted on political discussion sites on the Web as well as via emails to organizational staff representatives. 139 activists responded. ${ }^{20}$ The 10 artists most often cited: Bob Dylan (listed by 29 respondents), Rage Against the Machine (14), Pete Seeger (14), John Lennon (13), Phil Ochs (12), Woodie Guthrie (11), Bob Marley (9), Neil Young (9), Joan Baez (8), and U2 (7). Ten fan blogs were collected for each of the 10 artists for a total of 100 blogs, using the same search engine and sampling process used to derive the first sample.

The blog samples were then compared via computer-assisted content analysis. Linguistic Inquiry and Word Count (LIWC) software was used to test two basic hypotheses. Each blog was independently analyzed using LIWC to determine the percentage of text in each that matches words in a dictionary of political terms. A mean percentage for each sample was then derived and the blog percentages were compared via an independent samples $t$ test, using SPSS (Statistical Package for the Social Sciences) software.

\section{An Explanation of Computer Assisted Content Analysis}

Before presenting the hypotheses it is important to explain LIWC and dictionary-based computer content analysis methodology, in general. LIWC testing is predicated on two basic assumptions. The first is that the words in a given dictionary correspond in some meaningful way to the topic and dictionary label. The reader can judge whether or not that is the case with the dictionary of political terms we created to indicate political content. ${ }^{21}$ These terms served as indicators of political discourse in the blogs. While not perfect as absolute indicators (the terms are sometimes mentioned in relatively apolitical contexts), they are useful comparative indices, especially in the aggregate. In other words, if there is a higher incidence of these terms in one large sample of texts (fan blogs of political pop stars) when compared to another large sample of texts (fan blogs of top-selling pop stars), then it is reasonable to conclude that there is a higher frequency of political content in the first sample.

However, comparison is key. A dictionary-based content analysis does not provide an absolute measurement of content, but rather comparatively measures relative differences between texts. The

\footnotetext{
${ }^{19}$ See L. Ingraham, Shut up \& sing: How elites from Hollywood, politics, and the UN are subverting América (Washington, D.C.: Regnery Publishing, 2003).

${ }^{20}$ A chapter based on the survey will appear in a forthcoming book edited by Elizabeth Bird, entitled The Anthropology of News and Fournalism, published by Indiana University Press.

${ }^{21} \mathrm{The}^{\star}$ at the end of a term or root signifies that all extensions of that term or root will be counted: corporat ${ }^{\star}$, monopoly, nation ${ }^{\star}$, country $^{\star}$, school $^{\star}$, institution ${ }^{\star}$, organization ${ }^{\star}$, establishment ${ }^{\star}$, association ${ }^{\star}$, united states ${ }^{\star}$, politic $^{\star}$, Left $^{\star}$, Right $^{\star}$, Elect $^{\star}$, liber ${ }^{\star}$, conservative ${ }^{\star}$, vot $^{\star}$, president ${ }^{\star}$, congress $^{\star}$, legislat ${ }^{\star}$, senat ${ }^{\star}$, bill, law ${ }^{\star}$, polic ${ }^{\star}$, lobby $^{\star}$, impeach $^{\star}$, movement $^{\star}$, activis $^{\star}$, rall ${ }^{\star}$, demonstrat ${ }^{\star}$, amendment, arrest ${ }^{\star}$, boycott ${ }^{\star}$, debate $^{\star}$, reform ${ }^{\star}$, fundrais ${ }^{\star}$, communi $^{\star}$, socialis ${ }^{\star}$, grassroot ${ }^{\star}$, primar $^{\star}$, peace, war ${ }^{\star}$, inva $^{\star}$, empire ${ }^{\star}$, candidate ${ }^{\star}$, cabinet, coalition $^{\star}$, commission $^{\star}$, committee, delegate ${ }^{\star}$, republic ${ }^{\star}$, democra $^{\star}$, department ${ }^{\star}$, military ${ }^{\star}$, court $^{\star}$, justice, leader ${ }^{\star}$, assembl ${ }^{\star}$, mandate ${ }^{\star}$, referndum ${ }^{\star}$, public interest, author ${ }^{\star}$, justice ${ }^{\star}$, petition ${ }^{\star}$, platform ${ }^{\star}$, rul $^{\star}$, order $^{\star}$, oath $^{\star}$, oppose $^{\star}$, hearing ${ }^{\star}$, nominat $^{\star}$, council $^{\star}$, protest ${ }^{\star}$, parliament $^{\star}$, constitution ${ }^{\star}$, chairman, chairperson, imperialis ${ }^{\star}$, represent ${ }^{\star}$, labor ${ }^{\star}$, human right ${ }^{\star}$, gov ${ }^{\star}$, system ${ }^{\star}$, elect ${ }^{\star}$, citiz $^{\star}$, public $^{\star}$, municipal, nation. ${ }^{\star}$
} 
absolute proportions of a given dictionary's terms appearing in a text sample tell us practically nothing about that text. For example, if two percent of a large sample of documents was comprised of terms appearing in an LIWC dictionary entitled "Anger," this does not mean that two percent of the sample is "angry." One would have to compare that sample to another in order to determine if its content is relatively angrily toned in comparison. Once again, these terms are simply indicators. No software program can accurately assess what percentage of a document is "angrily toned," "political," or "emotionally positive" in absolute terms (even human coders have trouble doing so consistently and can never cover all of the polysemic possibilities). Therefore, computer assisted content analysis is largely a comparative research tool, useful for objectively comparing two or more samples containing large amounts of text.

Furthermore, it should be remembered that only a small portion of any text is comprised of specifically targeted terms, no matter how important they are to forming that text's overall meaning. For example, although "God" is the most important term in the Christian Bible, the word itself comprises only a small percentage of total text. There are 774,746 words in the Bible. The word "God" is used 4,370 times, making it less than one percent of the total text. Only through statistical comparison with another text, such as a biology textbook, could the researcher determine the relative importance of "God" in the Bible. Although both would yield small percentages in absolute terms, direct statistical comparison would lead us to the conclusion that "God" is more thematically relevant to the Bible than to a biology textbook.

Because it counts actual words, which serve as indicators of larger content themes, those more accustomed to human coding procedures might find that the numbers resulting from computer coding appear to be very low. However, the difference is a natural outcome of what is being counted. Dictionary-based computer content analysis counts specific words, whereas human coders make wholesale assessments of large textual elements. Our interest in assessing large blog samples and a desire for objective assessment of these texts led us to a computer-assisted methodology.

\section{Hypotheses}

$\mathbf{H}_{1}$. Fans of political pop musicians will more frequently discuss politics in their blogs than fans of top-selling pop musicians.

Test. Blogs written by fans of political pop musicians will contain a significantly greater frequency of the terms in the "Political" dictionary compared to blogs written by fans of top-selling pop musicians.

But how political is political? In order to create a standard for what would constitute a highly politicized fan discourse, a third sample of blogs was tested in order to derive an upper standard. That sample consisted of blogs containing the terms "music" and "politics" in their titles. The following hypothesis was tested using the third blog sample:

$\mathbf{H}_{2}$. In terms of mean percentage of political terms employed, blogs written by fans of political musicians will be more similar to blogs written by fans of top-selling pop musicians than either is to blogs explicitly dedicated to the political aspects of music.

Test. Fans of political pop musicians will write significantly less about politics in their blogs than bloggers whose explicit, titular interest is to write about "music" and "politics." The mean percentage of political terms appearing in blogs written by fans of political pop stars will be closer to the mean 
percentage of political terms appearing in blogs written by fans of top-selling pop musicians than either sample mean is to the mean percentage of political terms appearing in blogs containing the terms "music" and "politics" in their titles.

Rationale: The goal of this hypothesis and test is to begin answering a basic question: how political is political? Are fans of political pop music more like pop music fans, in general, or more like bloggers whose explicit interest is musical politics?

Note: Because the attempt was to determine a gross standard for what constitutes a "highly politicized" discourse concerning music, only 10 blogs were used to produce the "music" and "politics" mean. Finding 100 blogs with the terms "music" and "politics" in the title was neither possible nor necessary in order to create this comparative standard.

\section{Results}

$\mathrm{H}_{1}$ was supported. A cumulative mean of 1.1 percent of the blog text written by fans of political pop musicians is comprised of terms from the Political dictionary, roughly double the percentage found in blogs written by fans of top-selling pop stars, which is 0.5 . That difference proves to be significant according to an independent samples $t$ test. When equal variances are not assumed, the $t$ test for equality of means results in a significance value of .000 .

Once again, keep in mind that the method uses indicator terms for relative assessment. This does not mean that only 1.1 and 0.5 percent of the samples, respectively, are "political" in tone or orientation. However, it is very strong evidence that fans of political musicians are engaging in more political discourse than fans of the top-selling pop stars.

\begin{tabular}{|cc|c|c|c|c|}
\hline & Type & $\mathrm{N}$ & Mean* & $\begin{array}{c}\text { Std. } \\
\text { Deviation }\end{array}$ & $\begin{array}{c}\text { Std. Error } \\
\text { Mean }\end{array}$ \\
\hline Political & Political & 100 & $\mathbf{1 . 0 8 2 4}$ & 1.15658 & .11566 \\
& Top Ten & 100 & $\mathbf{. 5 0 3 7}$ & .58004 & .05800 \\
\hline
\end{tabular}

.000 significance value based on 2-tailed independent samples t-test for equality of means

Table 1. Mean frequency of "Politics" dictionary terms found in blogs written by fans of political musicians vs. blogs written by fans of top selling pop artists

$\mathrm{H}_{2}$ was also supported. A cumulative mean of 2.7 percent of the words from "music" and "politics" blogs appear in the "Political" dictionary, a percentage over 2.5 times greater than the mean for blogs written by fans of political pop musicians (1.1), and over five times greater than the mean for blogs written by fans of top-selling musicians (0.5). This result indicates that blogs written by fans of political pop musicians, while significantly more political than blogs written by top-selling pop fans, are not necessarily "highly political." 


\section{Discussion}

Content analysis indicates that fans of political musicians engage in more political communication than fans of top-selling pop musicians. In that regard, the political content of the music is mirrored in fan discourse. At a certain level, politics could be said to matter to these fans. While by no means can we say that the music or musicians cause fans to engage in political discussion, there is clearly a political relationship between the musicians, music, and fan blogging.

However, the results for the second test require us to heavily qualify this conclusion. While fans of political pop musicians engage in more political discourse than fans in general, their discussions cannot be described as highly political.

\section{Future Research}

It is clear that the frequency of political content in fan discussions is related to the political reputations of the artists under discussion. However, we are unable to say anything more specific about the nature of the two fan discourses. That is left to qualitative inquiry.

Yet, a third, post-hoc test leads us to believe that quantitative content analysis could yield more specific information about fan cultures and discourses. LIWC contains 64 dictionaries of potential relevance to blog text. Pennebaker et. al. (2007) have designed and painstakingly tested each of these dictionaries. They represent a robust and rigorous means to comparatively test texts for differences in rhetorical tone and literal content. ${ }^{22}$

Only 10 of the 64 dictionaries evidenced statistically significant differences between the blog samples, further reinforcing the position that, overall, the two fan blog samples are more alike than unlike (even in a statistical "fishing expedition" one would expect at least four dictionaries to evidence differences in the tested texts under conditions of random chance).

However, there is some evidence of a pattern when looking at those ten differences. Specifically, blogs written by fans of political musicians contain a significantly higher frequency of terms from the following dictionaries: Negative Emotion, Anger, Death, Religion, and She/He (which literally contains just two terms: "she" and "he"). Blogs written by fans of the top-selling musicians demonstrated a significantly higher frequency of terms from the following dictionaries: Future, Biology, Body, Ingest, and Money.

In other words, there might be more nuanced differences between these two fan populations. The heightened discussion of negative emotions, anger, death, and religion indicates fans of political pop musicians may delve into more serious topics than top-selling pop fans, issues that are somewhat taboo in sex-obsessed mainstream pop. Conversely, the emphasis on biological and somatic terminology, money, and ingestion (consumption?) might outline a profile of fans of top-selling pop stars that differentiates them from fans of political musicians. In other words, it might not just be a matter of political vs. apolitical music, musicians, and fans, so much as the mainstream audience's emphasis on the central political ideology of the present: consumption.

\footnotetext{
${ }^{22}$ Pennebaker, J.W., Chung, C. K., Ireland, M., Gonzales, A., and Booth, R. J.The Development and Psychometric Properties of LIWC2007. This article is published by LIWC.net, Austin, Texas, in conjunction with the LIWC2007 software program. Correspondence should be sent to Pennebaker@mail.utexas.edu.
} 
Only the difference in political discourse was hypothesized and fully tested here. However, further research into each of the above themes is warranted.

\section{Conclusion}

The rigorous methodology used here led to a fairly basic conclusion: fans of political music engage in significantly more political discourse than fans of mainstream pop musicians. Therefore, the answer to the title question is "yes." Political pop appears to attract more political fans.

However, it is important to remember that political expression is just one of many variables drawing fans to political pop musicians. Based on these results we have little evidence that political concordance is a primary factor in fan interest. Nevertheless, for artists who produce political pop, this study presents heartening evidence that their political messages matter. Their fan bloggers discuss politics more often than fans of top-selling pop musicians. This is among the first and firmest evidence that politics in pop actually matters to fans.

Regarding the significance of political pop research, Holbrook and Hill argue that "current theories of media and politics do not sufficiently account for the impact that non-news sources of political information have on public opinion" and that "an overly strict definition of politically relevant media" dominates the field. ${ }^{23}$ Similarly, Richards encourages scholars of political communication to study popular culture as part of the political process. The "boundaries between different spheres of life" have been weakened, Richard argues, and "politics is now interwoven with popular culture". ${ }^{24}$

The political role of television entertainment is better understood than that of popular music, where the study of political discourse has remained largely focused on production and performance, especially in the form of genre and movement history, biography, and analyses of live performance. ${ }^{25}$ Ethnographic and audience research with an eye toward political implications is less common, and content analysis is even more rare. ${ }^{26}$ Hopefully, attention to the relationship between music and politics will help us to better understand the actual and potential roles popular musics play, or could play, in a democratic society.

\section{References}

Bleich, S., \& Zillmann, D. "Enjoyment and consumption of defiant rock music as a function of adolescent rebelliousness." Journal of Broadcasting \& Electronic Media 35, vol. 3 (1991): 351.

Brown, C. Politics in music. Atlanta: Farsight Press, 2008.

Denisoff, R. S. and M. H. Levine. "Brainwashing or background noise: The popular protest song." In The sounds of social change: Studies in popular culture, eds. R. S. Denisoff and R. A. Peterson, 213-221. Chicago: Rand McNally, 1972.

\footnotetext{
${ }^{23}$ R. A. Holbrook and T. G. Hill, "Agenda-setting and priming in prime time television: Crime dramas as political cues," Political Communication 22, vol. 3 (2005): 278.

${ }^{24}$ B. Richards, "The emotional deficit in political communication," Political Communication 21, vol. 3 (2004): 340.

${ }^{25}$ See S. Livingstone, "The challenge of changing audiences - or, what is the audience researcher to do in the age of the Internet?" European Fournal of Communication 19, vol. 1 (2004): 75-86; and L. van Zoonen, "Audience reactions to Hollywood politics," Media, Culture E Society 29, vol. 4 (2007): 531-547.

${ }^{26}$ M. Stahl, "To hell with heteronomy: Liberalism, rule-making, and the pursuit of "community' in an urban rock scene," Fournal of Popular Music Studies 15, vol. 2 (2003): 140-165.
} 
Devenish, C. Rage Against the Machine. New York: St. Martin's Press, 2001.

Drewett, M. “The eyes of the world are watching now: The political effectiveness of 'Biko' by Peter Gabriel." Popular Music E Society 30 (2007).

Fischlin, D. Rebel Musics : Human rights, resistant sounds, and the politics of music making. Montréal: Black Rose Books, 2003.

Fox, W. S., \& Williams, J. D. "Political orientation and music preference among college students." Public Opinion Quarterly 38, vol. 3 (1974): 352.

Frith, S. Music for pleasure : Essays in the sociology of pop. New York: Routledge, 1988.

Frith, S. Performing rites: On the value of popular music. Cambridge, MA: Harvard University Press. 1996.

Garofalo, R. Rockin' the boat: Mass music and mass movements. Boston: South End Press, 1992.

Garofalo, R., Bragg, B., Cheng, T., Fast, S., Frith, S., George-Warren, H., et al."Who is the world?: Reflections on music and politics twenty years after live aid." Journal of Popular Music Studies 17, vol. 3 (2005).

Gracyk, T. I wanna be me: Rock music and the politics of identity. Philadelphia: Temple University Press, 2001.

Grossberg, L. We gotta get out of this place : Popular conservatism and postmodern culture. New York: Routledge, 1992.

Holbrook, R. A., \& Hill, T. G. "Agenda-setting and priming in prime time television: Crime dramas as political cues." Political Communication 22, vol. 3 (2005): 277-295.

Ingraham, L. Shut up E sing: How elites from Hollywood, politics, and the UN are subverting América. Washington, D.C.: Regnery Publishing, 2003.

Jackson, D. J., \& Darrow, T. I. A. "The influence of celebrity endorsements on young adults' political opinions." Harvard International Journal of Press/Politics 10, vol. 3 (2005): 80-98.

Livingstone, S. "The challenge of changing audiences - or, what is the audience researcher to do in the age of the Internet?" European Journal of Communication 19, vol. 1 (2004): 75-86.

LIWC. Table 1: LIWC2007 Output Variable Information. Retrieved 1 May 2008, from website: http://www.liwc.net/descriptiontable1.php.

Margolick, D. Strange fruit : Billie Holiday, café society, and an early cry for civil rights. Philadelphia: Running Press, 2000.

Mattern, M. Acting in concert : Music, community, and political action. New Brunswick, NJ: Rutgers University Press, 1988.

Pennebaker, J.W., Chung, C. K., Ireland, M., Gonzales, A., and Booth, R. J., (2007). The Development and Psychometric Properties of LIWC2007. This article is published by LIWC.net, Austin, Texas, in conjunction with the LIWC2007 software program. Correspondence should be sent to Pennebaker@mail.utexas.edu.

Platoff, J. "John Lennon, 'Revolution,' and the politics of musical reception." Journal of Musicology 22, vol. 2 (2005): 241-267.

Pratt, R. Rhythm and resistance: The political uses of American popular music. Washington: Smithsonian Institution Press, 1994.

Prinsky, L. “'Leer-ics' or lyrics: Teenage impressions of rock 'n' roll.” Youth \& Society 18, vol. 4 (1987): 384-397. 
Richards, B. "The emotional deficit in political communication." Political Communication 21, vol. 3 (2004): 339-352.

Robinson, J. P., \& Hirsch, P. M. (1972). "Teenage response to rock and roll protest songs.” In The sounds of social change: Studies in popular culture, ed. R. S. Denisoff and R. A. Peterson, 222-231. Chicago: Rand McNally (1972).

Rodnitsky, J. "The decline and rebirth of folk-protest music." In The resisting muse: Popular music and social protest, ed. I Peddie, 17-29. London: Ashgate, 2006).

Stahl, M. "To hell with heteronomy: Liberalism, rule-making, and the pursuit of 'community' in an urban rock scene.” Journal of Popular Music Studies 15, vol. 2 (2003): 140-165.

van Zoonen, L. "Audience reactions to Hollywood politics." Media, Culture \& Society 29, vol. 4 (2007): 531-547.

Weglarz, K. "From music to voting blocs: An analysis of popular musicians and political persuasion." Paper presented at the Annual Conference of the International Association for the Study of Popular Music, St. Catharines, Ontario, Canada, May 2008.

\begin{abstract}
Political messages in popular music clearly matter to the musicians who produce them, but do they matter to fans? The answer, based on quantitative content analysis, is a heavily qualified "yes." Computer-assisted content analysis was used to compare 100 blogs written by fans of political pop musicians with an equal number of blogs published by fans of top-selling pop stars. Fans of political musicians discuss politics more often than followers of apolitical pop stars, indicating that politics matters to them. This is the firmest evidence to date of a relationship between the level of political content in music and the level of political interest among audiences. Implications of the findings for the field of popular music research are discussed.
\end{abstract}

